\title{
Morar na rua: realidade urbana e problema público no Brasil
}

\author{
Living on the streets: urban reality \\ and a public problem in Brazil
}

Cristina Almeida Cunha Filgueiras [1]

\begin{abstract}
Resumo
0 artigo analisa, à luz da sociologia dos problemas públicos, a questão do morar na rua no Brasil, a qual passou a ocupar progressivamente, desde 0 final do século XX, lugar relevante na agenda das políticas urbana, social e dos direitos humanos. 0 artigo examina, ainda, o tratamento dado aos moradores de rua em algumas capitais brasileiras na Copa de Futebol de 2014, quando ficaram em evidência antigas tensões do controle da sua presença nos espaços urbanos. Foram consultados documentos de órgãos públicos, organizações não governamentais e mídia impressa e digital. $\mathrm{A}$ conclusão destaca que identificação e tratamentos dados ao morar na rua resultam de investimentos de diversos atores em face de um problema que reúne desafios políticos e urbanos.
\end{abstract}

Palavras-chave: população de rua; cidade; política pública; vida urbana; Copa da Fifa.

\begin{abstract}
This article examines the issue of living on the streets in agenda setting in Brazil and shows that the problem occupies an important place in the media and in the political and urban spaces. Based on information from documents of public agencies, entities, non-governmental organizations and the media, events and decisions related to the homeless in several Brazilian cities are analyzed. Prominence is given to the effects of the 2014 World Cup on the situation of the homeless in host cities. Seen by segments of the society and of the government as sources of threats, the homeless are the ones who are constantly threatened - even by urban projects.
\end{abstract}

Keywords: homeless; city; public policy; urban life; World Cup. 


\section{0 morar na rua visto pela sociologia de problemas públicos}

0 "morar na rua" não é apenas um problema social, mas também um problema público: ele ocupa um lugar incontornável no espaço público, midiático e político (regulamentar, legislativo) e nos espaços públicos urbanos (ruas, praças, jardins públicos, espaços intersticiais). Sua dimensão pública associa de forma inextricável os desafios políticos e urbanos: a presença de pessoas sem abrigo nos espaços urbanos interroga as capacidades das nossas democracias a enfrentar a exclusão dos mais vulneráveis, seja pelas acomodações cotidianas da urbanidade seja pela ação pública na qual estão engajados associações e poderes públicos". (Choppin, Gardella, Jouve e Pichon, 2013, p. 101; tradução nossa)

Como indicam os autores da citação, em destacada resenha da bibliografia francófona sobre o fenômeno sans-abrisme, na denominação de um fato social como problema público e no seu tratamento, estão envolvidos diversos tipos de processos sociais e políticos. A designação do morar na rua ${ }^{1}$ como problema público equivale, no nosso entendimento, ao que Neveu (2005, p. 7), chama de conversão de um fato social em objeto de preocupação, debate e ação.

Encontra-se em obra emblemática do sociólogo Gusfield (2014), cuja primeira edição em inglês foi publicada pela Universidade de Chicago em 1981, uma das mais importantes demonstrações de como um fenômeno social é promovido ao status de "problema público" como resultado da dinâmica cultural, social e política na qual há disputas entre atores quanto a delimitação e interpretação do problema, de suas causas e dos responsáveis, bem como em relação às práticas a serem adotadas em relação a ele. 0 estudo realizado por Gusfield sobre o problema público "motorista e uso de bebidas alcoólicas", tornou-se referência para a análise de como se constituem arenas nas quais narrativas, argumentos, justificações e proposições são apresentados em busca de tratar do interesse geral e da ordem pública e, com frequência, propondo modos de regulação.

Outro elemento importante a ser mencionado dentre aqueles examinados por autores que deram importante contribuição para a análise de problemas públicos é a formação de opinião pública, isto é, como um público como audiência determinada que se sente afetado pelo problema ou envolvido na proposição de como enfrentá-lo (Dewey, 1927; Cefai, 2014). Esse elemento não será, contudo, abordado neste artigo.

A politização do problema ganha outra dimensão quando se requer inseri-lo na agenda das políticas públicas, tomar decisões e implementá-las com um quadro normativo e institucional e recorrendo a instrumentos de ação. Forma-se um campo no qual atuam promotores do problema (aqueles que o colocam, mantêm e problematizam na esfera pública) e donos do problema (a quem a sociedade atribui a função e autoridade para tratar o problema), com frequência associados a conhecimentos profissionais e disciplinares (Neveu, 2015).

Definição e delimitação do problema público, bem como práticas, mudam ao longo do tempo (Brodiez-Dolino e Ravon, 2016). 0 processo de formação e evolução de um problema público não ocorre em uma sequência linear 
ou um movimento para adiante sem possibilidade de voltar atrás. Podem ocorrer descontinuidades, rupturas, mutação e a superposição ou convivência de camadas de elementos que pareciam superados. Além disso, a análise da trajetória de um problema público não se reduz à da sua emergência e de sua trajetória, e à dos interesses envolvidos. Trata-se também do exame dos obstáculos para que o problema ganhe generalidade, entre na agenda mediática e política e seja traduzido em categorias institucionais e jurídicas. 0 entendimento da questão, tal como as estratégias de ação, está sujeito a mudanças, pois o fenômeno pode evoluir assim como os atores envolvidos (ibid., p. 35). Ao analisar as mutações do problema público sans-abrisme e seu tratamento no caso da França, esses autores identificam, incialmente, os períodos de repressão à pobreza e à mendicância que levaram a colocar os pobres em asilos e instituições fechadas, por vezes com trabalho forçado. Abolidos esses mecanismos, por muito tempo o problema não recebeu tratamento governamental sistemático. Posteriormente, os que viviam na rua se tornaram uma questão social, parte da grande pobreza; os excluídos da sociedade capitalista e tratados na perspectiva do direito à assistência pública, sem que, contudo, as práticas repressivas tenham desaparecido totalmente. No período de extensão de direitos sociais, a abordagem da assistencial impôs-se, principalmente procurando limitar, pela gestão social, um problema que insistia em estender-se a partir dos anos 1970 com o desemprego e as mutações no mundo do trabalho. Nas últimas décadas do século XX, o problema passou a ser encarado como questão humanitária que requer ser gerido por ações de urgência (Cefaï, 2013), o que é um paradoxo, pois está instalado como problema crônico tendo em vista que as políticas sociais até então não conseguiram solucioná-lo. Finalmente, entrou na agenda das políticas públicas o housing first, uma forma de abordagem do problema orientada à parcela de moradores de rua mais fragilizados principalmente quanto à saúde mental. Os tipos de ação anteriormente mencionados não se excluem reciprocamente, porém em determinados períodos um enfoque se torna predominante e é visto com maior legitimidade.

Após termos apresentado alguns aspectos da contribuição da sociologia dos problemas públicos e sua relação com a literatura sobre o fenômeno do morar na rua, abordaremos a seguir o caso do Brasil. Não é nosso propósito no artigo examinar cabalmente todas as etapas e os atores associados ao problema do morar na rua no País. 0 recorte dado aqui diz respeito a como o fato de pessoas viverem nas ruas é apreendido como questão social e urbana apresentada como problema público desde o final do século XX. A contribuição deste artigo $^{2}$ é o exame da questão do morar na rua na agenda pública brasileira, demonstrando que o fato de existirem pessoas morando nas ruas, praças e debaixo de viadutos não o torna imediatamente um problema público. Para que isso ocorra é necessária uma construção do olhar, ou seja, que a opinião pública, diferentes atores, analistas e empreendedores de causas ou não, mais do que enxergarem os moradores de rua, identifiquem, na sua presença no espaço público, as questões sociais, políticas ou morais e, a partir disso, pautem estratégias de intervenção.

A análise apresentada baseia-se em consulta a documentos de órgãos públicos, 
entidades, organizações não governamentais e mídia. Na segunda parte do artigo, abordaremos os temas do uso do espaço urbano pelos moradores de rua e as reações à sua presença na cidade. Na terceira parte, serão apresentados os componentes mais destacados das reações governamentais no âmbito do governo federal, desde 2004, a graves acontecimentos de violência contra moradores de rua e, em 2009, o estabelecimento de uma política nacional para a população em situação de rua, centrada principalmente no campo da assistência social. Na quarta parte, será examinado o megaevento esportivo Copa Federação Internacional de Futebol (da Fifa) realizado no Brasil em 2014 e como, nessa ocasião, em algumas cidades que sediaram os jogos, o problema dos moradores de rua ganhou evidência nas arenas institucional, política e midiática. Na quinta parte, 0 artigo aborda procedimentos adotados por administrações municipais para a ordem urbana e seus impactos sobre quem vive nas ruas, assim como as tensões políticas e disputas jurídicas referentes aos direitos dessas pessoas. Na conclusão, é reiterado que a identificação, delimitação e tratamentos dados ao morar na rua resultam de investimentos de diversos tipos de atores em face de um problema cuja dimensão pública associa (como destaca a epígrafe) de forma inextricável os desafios políticos e urbanos. A análise apresentada baseia-se em consulta a documentos de órgãos públicos, entidades, organizações não governamentais e mídia.

\section{Corpos e pertences visíveis no espaço urbano}

Para administradores públicos, elas sempre foram vistas e tratadas como um problema. Para diversos comerciantes e moradores de bairros frequentados por elas, são um incômodo. Para grande parte das pessoas que circulam pelas ruas e calçadas, elas simplesmente não existem: são invisíveis. Para muitos (que não se deram ao trabalho de tentar compreender o que representam), seria melhor se não existissem. [...] Mas as pessoas em situação de rua existem, e para existir insistem em ocupar o lugar que lhes restou: as ruas e espaços dos grandes e médios centros urbanos. (Aiexe, 2011, p. 5; grifo nosso)

A existência de pessoas morando nas ruas inquieta quem vive ou visita uma cidade, os comerciantes, o poder público responsável pela gestão, regulação e fiscalização do território. Moradores de rua podem ser encontrados em logradouros públicos, becos, vias de circulação, passeios, praças, debaixo de viadutos, pontes e marquises, entradas de edifícios, lotes vagos, rodoviárias e abrigos de ônibus e em muitos outros lugares nos interstícios da cidade. Com frequência seus corpos e suas coisas (carrinhos de supermercado com pertences, papelões, caixotes, cobertores, cachorros, os objetos recicláveis que coletam para venda) tornam-se estorvo à circulação de pessoas e veículos. Essas pessoas são consideradas pelos demais moradores como indesejáveis, fora do lugar, poluidores do espaço urbano com seus 
corpos e pertences, "desencaixados espacial e simbolicamente" (Frangella, 2010, p.15). Nas ruas, elas não permanecem no mesmo lugar, deslocando-se pelo território em busca de locais para ficar ou dormir, alimentação, convívio, proteção, suprir necessidades e higiene pessoal, realizar trabalhos e atividades que Ihes deem renda. Elas frequentam lugares de distribuição de alimentos e roupas, restaurantes populares (se existirem), centros de atendimento diurno e os albergues públicos noturnos (se existirem, quando houver vagas e quando se sujeitarem às normas e condições).

A trajetória do morador de rua é eminentemente corporal. "Desprovidos de bens materiais, sem casa, absolutamente fora das práticas de consumo, envelhecendo nas ruas, corpo sujo e fétido que mimetiza no asfalto, o morador de rua aparece como uma ameaça às definições normativas do espaço urbano e às projeções corporais idealizadas" (ibid., p. 61). Incomodam pela sua presença, são marginalizados e outsiders, "corpos a mais" (Kasper, 2006). São barrados em prédios públicos, lojas, shoppings, bancos. Sua presença transgride a ordem espacial e infringe normas de ocupação, circulação e permanência nos espaços da cidade. Gerenciar tais conflitos da ocupação do espaço urbano é a principal razão para as medidas adotadas contra os corpos e pertences. Recorre-se, pois, à instalação de câmaras de segurança e à arquitetura antimendigo (grades, bolas de cimento, pinos de ferro e outros recursos de dissuasão adotados pelos proprietários de imóveis e pelas administrações municipais), adotam-se medidas de vigilância, disciplinamento e higienização do espaço urbano. Quando esses recursos não são efetivos para o controle da população de rua, pode-se chegar a recorrer à Guarda Municipal ou à Polícia Militar para expulsá-los.

Os moradores de rua disputam os espaços, e a guerra dos lugares na cidade é permanente: "se colocar barraca, colchão, fogareiro, montar um lugar para ficar, a prefeitura tira". Mecanismos de poder urbanístico, tais como os códigos de posturas e normas, além do poder de polícia com relação aos bens comuns, são utilizados pela administração municipal para coibir essa presença. Porém, sua aplicação revela a existência de conflitos entre princípios e conflitos de interpretação: a guarda municipal age para proteção aos bens públicos de uso comum (inclusive calçadas, praças, etc.), mas, qual o limite desse poder? Que objetos seria justificável recolher nessas ações? Se há objetos que estorvam as ruas e pertences das pessoas como documentos, cobertor e bolsa de roupas: quais bens são considerados "mínimo essencial"? A quem cabe discriminar? Em que situações o uso da força policial seria justificável?

0 uso e a forma de apropriação do espaço estão estreitamente associados a desigualdades sociais que caracterizam a sociedade brasileira, a concentração de renda e patrimônio, a segregação dos pobres e a assimetria no acesso a serviços públicos e oportunidades. No Brasil, a questão urbana e social é expressa nos mecanismos de exclusão econômica e social, que levam uma grande parcela da população às periferias ou a se instalar em áreas desvalorizadas nas regiões centrais, favelas, vilas e em bairros com acesso precário ou nenhum acesso aos recursos da cidade. Inclusive as políticas urbanas podem funcionar como instrumentos de exclusão, ao promover investimentos e projetos de infraestrutura que provocam remoção 
dos setores pobres de determinadas áreas, expulsando-os pela gentrificação porque sua capacidade econômica não lhes permite pagar os custos de continuar morando onde os preços se elevaram muito.

No capitalismo, a questão urbana está ainda associada à economia que transformou a cidade em commodity no novo ciclo de acumulação urbana, aprofundando a mercantilização das cidades (Harvey, 1996 e 2014). Nesse contexto, a governança empreendedorista promove intervenções em partes específicas da cidade (lugares), gerando melhorias capazes de atrair investimentos e alavancar o desenvolvimento econômico. Exemplos disso são a implantação de centros de convenções, parques tecnológicos e promoção de zonas turísticas e intervenções vinculadas a grandes eventos esportivos ou culturais (Ribeiro e Santos Jr., 2015).

A terra urbana é fonte de alta lucratividade, em especial aquelas parcelas mais bem localizadas e servidas pelos investimentos públicos. Projetos de revitalização de zonas degradadas na cidade, a renovação urbana das áreas centrais e a transformação de áreas em corredores culturais, dentre outros tipos de intervenção, têm transformado algumas cidades brasileiras. No entanto, para que essas intervenções aconteçam, é necessário equacionar diversos problemas, inclusive aqueles que dizem respeito à convivência no espaço urbano de diferentes atividades e diferentes segmentos sociais e até mesmo a localização de alguns tipos de equipamentos públicos, como é o caso daqueles destinados a atender os setores pobres da população. Há prefeituras que resistem a instalar na área central da cidade equipamentos e serviços para pessoas que vivem nas ruas e decidem pela sua localização em bairros muito distantes. Trata-se de estratégia para reduzir a permanência dos moradores de rua no centro, localização que, por vários motivos, favorece quem vive na rua (proximidade a comércio, locais de grande circulação de pessoas, proximidade de atividades com as quais podem obter alguma renda de forma esporádica).

Carneiro (2016) e CPAT/Parces (2017), em estudos sobre áreas de concentração de moradores de rua em duas cidades distintas Belo Horizonte, no Brasil, e Bogotá na Colômbia -, alertam que os processos de manutenção-tolerância-expulsão dessas pessoas de determinadas áreas urbanas podem ser perversos e, ainda que não sejam assim percebidos, não é raro que estejam conectados a estratégias de acumulação e apropriação de mais-valia urbana. A concentração de moradores de ruas em algumas áreas desvaloriza os imóveis, sobretudo as edificações/construções, porém o solo urbano continua sendo interessante, ainda que como reserva de terras. Por isso, o mercado de compra e venda desses terrenos não desconhece essas áreas. Investir em terreno cujo preço está baixo, desvalorizado pela degradação da área (e a presença próxima de moradores de rua é considerada como indicador disso) pode ser estratégico, se existe possibilidade de, no futuro, haver grande valorização da propriedade em vista da execução de projetos de requalificação urbana e de embelezamento e a remoção da população de rua. Nesses casos, pode ocorrer que certos atores do mercado especulem com o preço da terra e apostem na captação de mais-valia urbana gerada por investimentos públicos futuros. Assim, a presença dos moradores de rua e das cracolândias, ao mesmo tempo que desvaloriza o preço dos terrenos, é utilizada para justificar projetos 
urbanos, a necessidade de intervenções reestruturantes em áreas que são bem-localizadas no contexto geral da cidade.

\section{Brasil: morar na rua como problema público}

No Brasil, passou-se da repressão como única forma de tratamento do problema à assistência e à demanda por ações de proteção à vida dos moradores de rua. Até a Constituição Federal de 1988, na ausência de política pública, a assistência às pessoas que moravam na rua era praticada em geral em forma de caridade privada ou por meio de ações de caráter pontual do poder público. Com o novo marco constitucional, a assistência social passou a compor o tripé da seguridade (previdência-saúde-assistência) e um direito a ser garantido pelo Estado. Apesar disso, a sua entrada efetiva na agenda governamental ocorreu lentamente e enfrentou diversos obstáculos de ordem política, institucional, orçamentária e programática. No que tange à assistência social aos moradores de rua, somente em 2009 ela ganharia estatuto de política pública nacional.

Nas metrópoles brasileiras até os anos 1990, pedintes e pessoas que ficavam nas ruas sem ter onde se alojar eram vistos somente como um problema da ordem da caridade ou de ordem pública. Este último deveria ser abordado como questão de polícia e segurança urbana, por meio de práticas de expulsão apoiadas no enquadramento criminal pela lei da proibição à mendicância. Não havia políticas sociais para atender a essas pessoas nem àquelas sem trabalho que buscavam ajuda nas ruas ou migrantes pobres que vinham para as cidades em busca de oportunidades. A ação do poder público, se existia, era pontual e assistemática, restando para as pessoas serem atendidas com ações de indivíduos ou iniciativas de associações e entidades privadas. Os raros programas governamentais existentes eram destinados aos migrantes, em ações que reforçavam a transitoriedade e não a permanência das pessoas na cidade.

Porém, para setores críticos à repressão aos que moravam na rua e à culpabilização moral dessas pessoas, o problema deveria ser considerado como questão social, expressão das desigualdades estruturais da sociedade brasileira e dos processos de exclusão social que deveriam ser combatidos e corrigidos. 0 fenômeno morar na rua era então visto como reflexo visível do agravamento da questão social nas grandes cidades ou o resultado da migração (Giorgetti, 2006). Não existindo, no contexto das políticas governamentais, ações sistemáticas que enfrentassem o tema; este permanecia no âmbito das ações gerais de enfrentamento da pobreza.

A Constituição Federal de 1988 trouxe mudanças importantes que levaram à fundamentação das políticas sociais, a partir da década seguinte, e garantiram direitos sociais a parcelas empobrecidas da população. Merecem ainda destaques a Lei Orgânica da Assistência Social (Loas - lei n. 8.742), promulgada em dezembro de 1993; a criação do Sistema Único da Assistência Social (Suas)33; e a criação do Ministério do Desenvolvimento Social e do Combate à Fome (MDS) em 2004. 0 tratamento do problema público "morar na rua" seria feito de modo mais organizado dentro da política nacional de assistência social, um campo de 
política pública no seu conjunto recente que, aos poucos, foi ganhando institucionalidade, legislação própria, definições orçamentárias regulares, normativas para sua implementação em todo o território nacional pelos governos estaduais e municipais (Barbosa, 2018).

Em todo o País, a percepção e a interpretação do problema público do morar na rua foram impactadas por acontecimentos ocorridos na cidade de São Paulo em agosto de 2004, quando 16 pessoas foram atacadas, à noite, enquanto dormiam, na Praça da Sé, e sete delas morreram. Agressões contra moradores de rua, incluindo assassinatos, não eram novidade na cidade e no País, porém, em meio às constantes notícias de criminalidade e violência, elas, em geral, não recebiam destaque na opinião pública ou junto às autoridades do Estado. Contudo, nesse caso, que ficou conhecido como massacre da Sé, ${ }^{4}$ os crimes ganharam manchetes na mídia e rápida repercussão nacional e internacional, gerando intensa indignação na opinião pública e mobilização de organizações sociais. Além disso, o acontecimento tornou-se mais um motivo de disputa eleitoral entre os dois blocos político-partidários que ocupavam a prefeitura e o governo do estado (PT e PSDB, respectivamente). Eles atribuíram-se mutuamente a responsabilidade pelas mortes, pois o governo estadual era responsável pela segurança pública e o municipal, pelos programas de proteção social (De Lucca, 2016).

Controvérsia político-partidária à parte, não resta dúvida de que o acontecimento ganhou uma segunda vida com a repercussão geral, e fixaram-se na memória coletiva as ideias de massacre, descaso, escassa vontade para encontrar os responsáveis, ausência de justiça e crimes sem culpados e punição.
Uma série de ações voltadas às pessoas que moram na rua, surgidas posteriormente, tem em alguma medida relação com a repercussão desses crimes de 2004. Nos anos seguintes, o assunto "violência e discriminação contra os moradores de rua" passou a ser tratado na Secretaria Nacional de Direitos Humanos da Presidência da República, com acompanhamento das situações problemáticas e coordenação das ações de diversos órgãos públicos para enfrentá-las. Essas ações deram maior fôlego às mobilizações em defesa dos moradores de rua e levaram a instalar o tema diretamente no nível mais alto do governo brasileiro. 0 enfoque dos direitos humanos e defesa da vida deu novo enquadramento ao problema morar na rua e contribuiu, desde então, para colocar nesse campo as defensorias públicas e o Ministério Público. No final da década, com a estruturação da política nacional para a população em situação de rua, tais atores passariam a agir também na fiscalização de programas públicos voltados para a população em situação de rua. Como veremos na seção quatro, a respeito dos megaeventos esportivos em algumas cidades brasileiras, o entendimento de que moradores seriam problema não apenas do espaço urbano e social, mas, também, uma questão de direitos humanos, ampliou e diversificou os atores envolvidos com o problema.

Outro destaque a ser dado é o surgimento, também em 2004, de um novo ator político, o Movimento Nacional de População de Rua (MNPR), que assumiria protagonismo decisivo para a defesa dos direitos das pessoas em situação de rua, contribuindo para a politização do tema. 0 movimento tornou-se interlocutor do poder público tanto no governo federal quanto em algumas capitais (Melo, 2016). 
Uma sequência de fatos e decisões no âmbito do governo federal culminou na criação, em 2009, da Política Nacional para a População em Situação de Rua, cujo propósito era promover o acesso dessas pessoas aos programas e ações setoriais nas áreas de educação, saúde, habitação, política de emprego, trabalho e renda, segurança, assistência social, transferência de renda e segurança alimentar. Estruturou-se um campo de políticas e ações específicas que reuniu iniciativas antes dispersas, fragmentadas em institucionalidade, que dependiam apenas da vontade de cada gestor municipal. Fruto das mudanças ocorridas em um curto período de poucos anos e que transformaram o contexto prévio que se mantinha há muito tempo, passou a existir um aparato institucional que produz o controle e 0 atendimento aos moradores de rua. As reações à chacina de agosto de 2004 em São Paulo não iniciaram o processo que levaria à adoção de uma política nacional, porém conferiram-Ihe maior celeridade, puseram em movimentos os atores já envolvidos com o problema e contribuíram para que outros atores surgissem.

Outro fato de grande relevância ocorrido no mesmo ano de 2009 foi a revogação do artigo da lei que considerava a mendicância como uma contravenção penal, sujeita à prisão de 15 dias a 3 meses. ${ }^{5}$ A criminalização da mendicância era, até então, recurso utilizado pelas autoridades municipais contra a presença dos moradores de rua e como justificativa à sua criminalização. Apesar da revogação do artigo, em documentos do Ministério Público referentes a ações de defesa dos moradores de rua no período da Copa de 2014, faz-se menção à necessidade de fiscalizar se as autoridades locais não estariam realizando prisões com o uso da justificativa de vadiagem ou mendicância (Conselho Nacional do Ministério Público, 2014).

No campo da política pública, um marco fundamental foi a decisão do MDS, de 2010, de cofinanciar e apoiar a implantação nos municípios de unidades do equipamento público Centro de Referência Especializado da População de Rua, para atendimento diurno, além de albergues noturnos e repúblicas. Em algumas cidades existiam anteriormente iniciativas e programas locais, que foram reajustados no novo contexto da política nacional. As diversas iniciativas que se seguiram, no âmbito governamental, demonstram que ocorreu, não apenas a identificação e colocação do problema em um frame, como também a sua normalização (com institucionalidade, orçamentos, atribuições, legislação, formação e capacitação de equipes profissionais, produção sistemática de estatísticas sobre os atendimentos e de estudos).

Tal como ocorre em outras áreas de políticas públicas no Brasil, o avanço da implantação da política de assistência social e da política nacional para a população de rua tem sido acompanhado de perto pelos ministérios públicos, tanto federal quanto estaduais. 0 tratamento ou gestão do problema público multidimensional morar na rua envolve intervenções de várias políticas setoriais, tipos de profissionais, especialistas e práticas.

É indispensável assinalar, ainda, a conexão do problema morar na rua com as políticas de combate às drogas. Nas cidades brasileiras, o consumo do crack nos espaços urbanos provocou nova configuração do problema morar na rua, e com ela entraram, no campo das políticas para a população de rua, outros atores, especialistas e dispositivos. 0 enfrentamento 
do problema faz-se por meio de duas estratégias dos campos das políticas públicas da saúde e da segurança pública. A conexão que se estabelece, no caso dos moradores de rua, acaba sendo menos com a política de saúde do que com a de segurança pública e combate às drogas, em que predominam as ações de repressão (Medeiros, 2015). Nos anos recentes, cresceu novamente a criminalização dos moradores de rua, que parecia ter sido amenizada pelo entendimento e delimitação do problema morar na rua, em termos de assistência e de direitos humanos/proteção à vida. Apesar das mudanças que foram se realizando na postura do Estado, desde o final dos anos 1990, em relação à população em situação de rua, o poder público não deixou de praticar ações com a perspectiva de controle e repressão. Atualmente, convivem ações estatais por vezes divergentes e até conflitantes entre as políticas sociais, urbanas, de segurança pública e de direitos humanos.

Como vimos, o problema do morar na rua instalou-se na agenda pública, passou por mutações, é mobilizado por "empreendedores de causas" e de políticas que agem para denunciá-lo, abordá-lo e reduzi-lo. Tudo isto sem deixar de ser um problema da cidade, da ocupação e do uso do espaço urbano, sentido no cotidiano e com capacidade para afetar os demais moradores da cidade. Além da ocupação do espaço da cidade pelos moradores de rua, está presente, nos municípios brasileiros, a tensão com relação aos direitos e ao papel dos órgãos de controle e do Ministério Público. Tal tensão se manifestou de modo especial na preparação e no período de realização da Copa da Fifa de 2014, como veremos a seguir.

\section{Os moradores de rua e a Copa de 2014}

A preparação e a realização de três grandes eventos esportivos no Brasil constituem oportunidades para analisar o tratamento aos moradores de rua. Os eventos foram a Copa das Confederações de futebol, realizada em 2013, a Copa do Mundo de futebol de 2014 e os Jogos Olímpicos de 2016. Abordaremos aqui a Copa de 2014.

É necessário examinar o significado dos megaeventos no contexto amplo das cidades e do desenvolvimento urbano, visto que eles estão vinculados à adoção dos princípios do empreendedorismo urbano pelas metrópoles brasileiras e da nova rodada de mercantilização das cidades. Assim como ocorreu em outros países onde se realizaram eventos desse tipo, nas cidades brasileiras os grandes eventos esportivos foram vistos como estratégia para atrair financiamentos e investimentos que possibilitariam dinamizar as economias das regiões metropolitanas e também como oportunidade de promover transformações urbanas em cada cidade.

Os jogos da Copa de 2014 ocorreram em Manaus, Cuiabá, Fortaleza, Natal, Recife, Salvador, Rio de Janeiro, Belo Horizonte, Brasília, São Paulo, Curitiba e Porto Alegre. Para cada uma dessas cidades, foi elaborada uma "matriz de responsabilidades", indicando empreendimentos que seriam realizados e a competência do financiamento de cada nível de governo e da iniciativa privada. Foram detalhadas responsabilidades em obras de infraestrutura urbana quanto a reforma e adaptação dos estádios, 
reforma de terminais de passageiros, obras viárias, corredores de transporte, infraestrutura de turismo e, ainda, reformas e ampliação de aeroportos. Os focos centrais dos investimentos foram infraestrutura de estádios e turística, mobilidade urbana, melhoria do parque hoteleiro e segurança pública. Muitas dessas obras provocaram a remoção de comunidades de baixa renda das áreas urbanas a serem valorizadas, levando a reassentamento em áreas periféricas, indenização ou simplesmente despejo (Santos Jr., 2014, p. XII). Essa foi uma das razões que levou críticos e movimentos organizados a questionar os legados da Copa, no reconhecimento de que os resultados não teriam sido positivos para diversos setores da população.

Para a preparação para a Copa de 2014, foram feitas várias mudanças no marco legislatório brasileiro (Proni e Silva, 2012, p. 10). Dentre as mudanças, estão as medidas provisórias que possibilitaram o endividamento das cidades-sede além do permitido pela Constituição, a concessão de isenção fiscal a obras relacionadas à realização da Copa e nas importações de bens ou mercadorias relacionadas à organização do evento. Houve, ainda, a simplificação de procedimento de contratações públicas. Surgiram várias denúncias de que o gasto de recursos públicos em muitas obras teria ultrapassado o previsto, além da ocorrência de precarização de empregos (principalmente os empregos temporários gerados no setor da construção civil) e leniência dos poderes públicos em fiscalizar as condições das obras. A Lei Geral da Copa (lei n. 12.663 de junho de 2012), que teve como objetivo estabelecer as regras para a exploração e a proteção dos direitos comerciais, dos vistos de entrada e das permissões de trabalho, de venda de ingressos, entre outros (Brasil, Câmara dos Deputados, 2012), foi fortemente criticada, por organizações da sociedade civil, profissionais do direito e acadêmicos, por não respeitar a soberania do País, impor muitas restrições à população, conceder facilidades aos organizadores dos eventos, dentre outros aspectos (Repolês e Prates, 2015).

0 balanço final dos investimentos realizados para a Copa 2014, tomando-se em conta, principalmente, as parcerias público-privadas e a proteção dos direitos econômicos da Fifa e de seus patrocinadores, teria sido a "socialização dos custos e privatização dos ganhos" (Tonucci Filho, Scotti e Motta, 2014, p. 27). A geração de emprego mais significativa foi de empregos temporários associados às obras de infraestrutura (construção civil) e de atividades no período do evento.

As mudanças na legislação federal e nas legislações municipais para atender aos compromissos com a realização da Copa e a exigência da Fifa de exclusividade de comércio a empresas patrocinadoras do megaevento, com proibição de comércio de ambulantes e outros em perímetro de $2 \mathrm{~km}$ ao redor dos estádios, provocaram a crítica de instalação da cidade de exceção (Articulação Nacional dos Comitês Populares da Copa, 2014, p. 7).

Foram estabelecidas, em cada cidade onde ocorreriam jogos, zonas de restrição comercial e de circulação que geraram consequências negativas para os que moravam na rua. Houve denúncias, na mídia e em manifestações, tanto de comitês populares quanto do ministério público (Procuradoria da Defesa do Cidadão, 2013), de remoção forçada para abrigos, recoIhimento dos pertences nos espaços públicos, higienização de zonas centrais ou turísticas e 
na proximidade de estádios. As práticas dos agentes públicos de incomodar, fazer circular, deslocar as pessoas que dormem nas ruas, moIhar e apreender os seus pertences, feitas com justificativas associadas a razões sanitárias, de segurança pública e de combate ao crack não constituíam uma novidade, porém intensificaram-se com a Copa.

A Copa de 2014 efetivamente deixou legados na infraestrutura urbana. Do ponto de vista social, contudo, esses legados foram vistos como causadores de gentrificação. As intervenções teriam sido pensadas quase que exclusivamente para a circulação de turistas e torcedores nos dias de jogos do mundial e priorizaram alguns espaços, notadamente as áreas mais ricas e os centros urbanos (Pinheiro et al., 2015). A mercantilização do espaço urbano foi amplamente fortalecida. 0 evento esportivo afetou a configuração socioespacial das cidades brasileiras no que diz respeito à questão habitacional com os processos de remoção e desapropriação provocados pelas obras de preparação das cidades para receber os jogos e os visitantes e também por causa da valorização imobiliária dos espaços que receberam investimentos. Urbanistas apontaram a violação do direito à moradia e desrespeito a diversos parâmetros legais que regem o tema, tendo como um dos seus principais resultados a relocalização dos pobres nas cidades e, consequentemente, o aumento da segregação e a desigualdade socioespacial (Castro e Novae, 2015; Rolnik, 2013; Firkowski e Baliski, 2015; Repolês e Prates, 2015).

Desapropriações, deslocamentos e remoções compulsórias fazem parte dos relatos focados em 21 casos de vilas e favelas em Belo Horizonte, Curitiba, Fortaleza, Porto Alegre,
Recife, Rio de Janeiro e São Paulo e que, segundo os comitês dos afetados pela Copa e os movimentos sociais de luta por moradia, "teriam como pano de fundo comum o propósito da higienização, da 'faxina social', para o uso futuro de terras de alto valor imobiliário ou onde 0 Estado deseja repassar a mais-valia decorrente de seus vultosos investimentos à iniciativa privada" (Articulação Nacional dos Comitês Populares da Copa, 2014).

Preocupado com tal situação, o Ministério Público, que desde 2004 vinha atuando no tema de defesa dos direitos humanos das pessoas que vivem na rua e na defesa das garantias sociais, distribuiu, em 2012, aos procuradores o documento "Diretrizes para atuação. Defesa das pessoas em situação de rua durante a Copa do mundo". Nele, é recomendada a realização de audiências públicas sobre as ações da preparação da Copa e, durante o evento, de plantões para receber denúncias de violação de direitos da população em geral. Era conhecido que, nas cidades em que se realizaria a Copa, a permanência e a circulação de moradores de rua foram restringidas em diversas áreas (centro, zonas turísticas, proximidade de estádios ou vias de acesso a estes), na tentativa de torná-los invisíveis aos olhos dos visitantes (torcedores nacionais e estrangeiros; mídia nacional e estrangeira).

0 governo federal lançou, em agosto de 2012, a Agenda de Convergência Proteja Brasil, com o planejamento de um conjunto de ações intersetoriais e interinstitucionais abrangendo os três níveis da federação, agregando iniciativas do governo, dos sistemas de justiça, de responsabilidade empresarial e da sociedade civil, para serem colocados em prática nos grandes eventos, dentre eles a Copa das Confederações 
de 2013, a Copa de 2014 e os Jogos Olímpicos de 2016. 0 propósito explícito da agenda era a prevenção de violações de direitos de crianças e adolescentes, sendo recomendada a criação de comitês locais nas cidades-sede da Copa 2014, aos quais foi distribuído um guia de referência de proteção integral a crianças e adolescente e de prevenção de situações de violação dos direitos de outros públicos vulneráveis durante os eventos. Uma das recomendações era estruturar, para o dia do evento, um plantão social integrado com equipes itinerantes e reservar um espaço temporário de convivência para crianças e adolescentes com risco de sofrer violência, abusos e exploração, além de ações e espaços para atender a outros públicos em situação vulnerável, dentre eles as pessoas em situação de rua. ${ }^{6}$

Novamente em abril de 2014 as preocupações com a eventualidade de violação de direitos tocaram as autoridades. Reunidos em Brasília, promotores de Justiça, procuradores de Justiça e procuradores da República, representantes do Ministério Público da União e dos estados estabeleceram diretrizes comuns de atuação em face das pessoas em situação de rua durante o período de realização da Copa de 2014. Em documento, alertaram para que 0 Ministério Público atuasse visando a impedir a apreensão ilegal de documentos pessoais e bens pertencentes às pessoas em situação de rua, ações vexatórias e internações compulsórias que não fossem justificadas por laudos médicos circunstanciados. Ademais, os promotores deveriam impetrar ação de habeas corpus para fazer cessar restrição à liberdade da pessoa em situação de rua presa com fundamento na contravenção penal de vadiagem; zelar pela inocorrência de prisões arbitrárias ou medidas de restrição de liberdade baseadas em estigmas negativos e preconceitos sociais, tais como as prisões para averiguações ou intenção de criminalização da pobreza ou de movimentos sociais; adotar medidas judiciais promovendo a apuração da responsabilidade pelo abuso de autoridade (Conselho Nacional do Ministério Público, 2014).

A Agenda de Convergência lançada em 2012 foi retomada por governos estaduais e municipais nas cidades dos jogos da Copa, e uma agenda específica de cada cidade foi apresentada em conferências de imprensa, com participação dos órgãos municipais, representantes do Ministério Público do Estado e da Polícia Militar. Portanto, a iniciativa liderada pelo governo federal serviu para unificar o discurso dos órgãos públicos nos vários níveis de governo e padronizar as ações.

Às vésperas da Copa, o Centro Nacional de Defesa dos Direitos Humanos da População em Situação de Rua e Catadores de Materiais Recicláveis, CNDDH (2014) ${ }^{7}$ divulgou relatório nacional de "Violações de direitos da população em situação de rua nos meses que antecedem à realização da Copa do Mundo". 0 relatório aponta denúncias de violações em diversas capitais consistindo em recolhimento ilegal de pertences, remoção forçada de pessoas em vias de acesso e regiões próximas aos estádios e o encaminhamento dessas pessoas a abrigos já superlotados e com instalações precárias e inseguras.

Nas cidades onde se realizaram os jogos, alguns moradores de rua teriam, em razão das hostilidades em relação a eles, deslocado-se a outros lugares por iniciativa própria, permanecendo em locais mais distantes dos acontecimentos relacionados à Copa, retornando após 
o evento às áreas onde estavam habituados a permanecer e a circular.

Os efeitos dos eventos esportivos no Brasil sobre os moradores de rua não fogem ao que fora observado em outras cidades do mundo que receberam eventos desse tipo e onde, invariavelmente, essas pessoas foram consideradas como "um problema à imagem da cidade-espetáculo a ser visibilizada no cenário internacional" (Barbosa, 2011, p. 89). Em Vancouver (Canadá), nos jogos olímpicos de inverno de 2010, o governo local contratou agentes de segurança privados para a expulsão dos moradores de rua das zonas comerciais. Em Seul (Coréia), na Copa da Fifa de 2002, a prefeitura retirou 300 moradores de rua de perto do estádio. Nas Olimpíadas de 1992, o governo de Barcelona (Espanha) manteve sob controle cerca de 400 moradores de rua (Horne e Manzenreiter, 2006).

Apesar das precauções e prescrições da Agenda de Convergência lançada em 2012, as iniciativas de governos municipais brasileiros dirigidas aos moradores de rua durante a Copa, justificadas como de proteção aos afetados, foram vistas por críticos como estratégias para esconder um problema social. É o que demonstra o caso de Fortaleza, onde as ações de abordagem visaram às áreas de maior concentração de turistas, especialmente a praia de Iracema, onde se localiza grande número de hotéis e foi local do Fifa FanFest. Respaldada na Agenda, a prefeitura da cidade promoveu, nos dias de jogos, atividades especiais e abrigo para moradores de rua e "uma FanFest só para eles". Mais que proteger os moradores de rua, tratava-se de evitar que participassem da FanFest "para todos" (Barros e Monte, 2017).

A presença notória de moradores de rua e pedintes em meio à festa da Copa e aos milhares de turistas nacionais e estrangeiros na praia cearense não era o que desejavam a Fifa e os poderes públicos. Por isso, foram oferecidos abrigo, atividades de lazer, alimentação nos dias da Copa, estritamente durante os horários de realização dos jogos. Foram instalados telões dentro dos abrigos para assistir aos jogos e, ainda, foram realizadas atividades lúdicas, brincadeiras, orientações pedagógicas e sessões de cinema dentro dos centros municipais especializados em atender pessoas em situação de rua (Centros Pop). Nesses dias, uma centena de profissionais da Secretaria do Trabalho e Desenvolvimento Social e da Secretaria da Educação saía às ruas da praia de Iracema, nos arredores da Arena do Castelão, terminais de ônibus e regiões estratégicas, como Barra do Ceará, praia do Futuro e toda a extensão da avenida Beira Mar, em busca de pessoas em situação de vulnerabilidade. Os agentes públicos negaram que adultos e crianças em situação de rua fossem o público-alvo da medida. A principal justificação era a proteção de crianças em risco, tais como os "filhos de ambulantes que não têm onde ficar enquanto os pais trabalham e crianças encontradas sem a companhia de pais ou responsáveis". Segundo reportagem da imprensa datada da época, agentes públicos entrevistados revelaram que "Os agentes fazem a abordagem social, supervisionam todos esses eventos e fazem o encaminhamento das crianças para as escolas". ${ }^{8}$ Os agentes governamentais questionados pelos jornalistas insistiam em destacar o foco da ação social, cujo objetivo seria resguardar crianças sujeitas à violência e à exploração sexual. Ademais, afirmaram que, no momento da abordagem social, " ninguém é forçado a ir para os abrigos". ${ }^{9}$ 
Apesar da iniciativa antecipada do governo federal, em diversas cidades observou-se que denúncias e críticas continuaram sendo feitas, indicando que, durante a preparação dos megaeventos esportivos, muitas prefeituras já utilizavam as políticas de ordem urbana promovendo operações de repressão, particularmente aos vendedores ambulantes, flanelinhas e moradores de rua. A imprensa divulgou amplamente casos de "operação limpeza" em algumas cidades. As ações das prefeituras envolveram conjuntamente a guarda municipal e as equipes sociais, notadamente da política de assistência social. A participação dos técnicos da área social gerou controvérsias. Em Curitiba, a prefeitura informou que a presença dos técnicos era para o convencimento das pessoas que viviam nas ruas a se deslocarem para os abrigos ou os equipamentos sociais, visando a garantir sua proteção. " Os moradores de rua são muito expostos, há insegurança, ações de violência, são muito visíveis e podem sofrer agressões". Questionada quanto à participação nas ações de recolhimento dos pertences de pessoas vivendo nas ruas, a prefeitura de Curitiba, através da fundação responsável pela política de atendimento à população de rua, justificou: "Nós apenas os convidamos para irem aos abrigos". ${ }^{10}$

A prefeitura de Belo Horizonte e o governo do estado de Minas Gerais foram alvos, alguns meses antes da Copa de 2014, de uma decisão judicial que determinou a não violação dos direitos dos moradores de rua e o não recolhimento de seus pertences e documentos pelo poder público. Foram denunciadas atuações consideradas ilegais de recolhimento de pertences (roupas, documentos, cobertores, alimentos e instrumentos de trabalho) feitas pelo poder público municipal com acompanhamento da Polícia Militar. Em face das acusações, em declaração à imprensa, o prefeito afirmou tratar-se de ações de proteção:

"Asseguro que a prefeitura de Belo Horizonte não fez e não fará ação de retirada compulsória ou de recolhimento de pessoas que moram nas ruas, pois elas têm os mesmos direitos dos outros cidadãos $e$ vão participar das atividades que a cidade oferecerá durante a Copa do Mundo. É uma ação de proteção desse público para que eles não sejam mais violados do que já são", segundo afirmou a coordenadora do Comitê de Acompanhamento e Monitoramento da População em Situação de Rua da Prefeitura de BH (PBH), destacando, ademais, que as ações são parte da Agenda de Convergência Proteção da População em Situação de Rua Copa do Mundo 2014.11

Ocorreram muitos pronunciamentos de órgãos de defensoria pública e de juízes do Ministério Público em cada uma das cidades da Copa a propósito do tratamento aos moradores de rua. A Equipe Multidisciplinar de Atendimento à População em Situação de Rua, da Defensoria Pública do Estado da Bahia registrou, de setembro de 2013 a junho de 2014, diversas denúncias de retirada forçosa da população em situação de rua das zonas fronteiriças ao Centro Histórico de Salvador e à arena Fonte Nova. A retirada visaria a dar garantia de segurança aos frequentadores do evento e, além disso, segundo Menezes et al. (2015),

proporcionar uma imagem dissimulada acerca da existência de populações vulneráveis evidenciando práticas higienistas com a população em situação de rua para receber os turistas da Copa do Mundo. Nos relatos das denúncias, são 
mencionados os elementos utilizados nas remoções dessa população dos centros urbanos, como: um caminhão da Limpurb4, acompanhado de duas viaturas postas uma de cada lado do caminhão, outro veículo utilizado para transportar as pessoas e um carro "despadronizado" com supostos assistentes sociais. Os pertences eram colocados no caminhão, como se fossem lixo. Algumas vezes as pessoas sofriam agressões físicas e até mesmo jatos de água eram direcionados a atingi-los, sendo que essa ação sempre era realizada durante a madrugada. A Defensoria Pública do Estado ajuizou uma Ação Civil Pública, para coibir as práticas de higienistas destinadas à população em situação de rua, que se configuravam de forma gradativa com a aproximação dos dias dos jogos do Mundial em Salvador.

Na cidade do Rio de Janeiro, no contexto de preparação e realização da Copa e dos Jogos Olímpicos, ganhou nova legitimidade a política municipal designada "Choque de Ordem" em vigor desde o dia 5 de janeiro de 2009 que, em nome do combate à desordem urbana e da segurança no espaço público, realizava operações de repressão a vendedores ambulantes, flanelinhas, moradores de rua, construções irregulares e publicidade não autorizada. Durante a Copa, centenas de moradores de rua foram levados para um abrigo na zona Norte da cidade, distante 60 quilômetros da região central (Comitê Popular da Copa e Olimpíadas do Rio de Janeiro, 2014).

Denúncias de ameaças a moradores de rua ocorreram em todas as cidades-sede da Copa. Os registros dão conta da grande quantidade de iniciativas e pronunciamentos de órgãos de Defensoria Pública, de juízes do Ministério Público em cada uma das cidades, assim como das equipes da política de Assistência Social e das guardas municipais. Estes foram os principais atores do setor público responsáveis, nos períodos os megaeventos esportivos, por ações relacionadas ao problema da presença de pessoas morando nas ruas das cidades, espalhando seus corpos e pertences nos espaços públicos.

\section{Remoções e disputas jurídicas não começaram e nem terminaram com a Copa 2014}

A Copa 2014 pôs em evidência que o problema do morar na rua é questão urbana, social e de direitos humanos e ainda chamou a atenção para o poder ordenador das prefeituras. No período de preparação da Copa, a tensão ficou manifesta, dado o contexto "de exceção" dos eventos, a necessidade de cumprir os compromissos com a Fifa e o cronograma de obras. Porém, em períodos e em cidades onde não há esses dois últimos ingredientes, remoções e disputas estão também presentes. As diretrizes de atuação contidas nos documentos do Ministério Público já citados (cartilha e Agenda de Convergência) e a preocupação com a legalidade das ações não se restringiram ao contexto dos megaeventos esportivos. É o que evidencia o caso de Belo Horizonte antes e depois da Copa. Aiexe (2011) mostra com clareza o núcleo de tensão urbano versus social em torno do problema na cidade:

Como entender o conflito entre ações de assistência, que procuram assegurar um mínimo existencial, e as de fiscalização, 
que se destinam a preservar os bens e espaços públicos? Enquanto uma opera sob a ótica jurídico-normativa do Sistema Único de Assistência Social (Suas), a outra funciona com base em um Código de Posturas e Instruções Normativas de âmbito interno, na esfera local. Enquanto uma proporciona abordagem social, documentação, encaminhamentos para equipamentos, a outra ocupava-se de retirar objetos e pertences (os mesmos documentos, além de medicamentos, etc.) de forma compulsória, quando não os expulsava dos espaços de uso comum do povo: praças, viadutos, marquises ou áreas ociosas. De um lado, atestavam a cidadania; de outro, comprovavam sua exclusão. Mas seriam inconciliáveis por natureza essas políticas, ou haveria uma relação de necessária complementaridade entre elas? (p. 7; grifos nossos)

As inquietações expressas na citação traduzem uma situação frequente em municípios brasileiros. Em Belo Horizonte, a prefeitura buscou segurança jurídica para sua atuação com instrumentos de gestão urbana que permitissem impedir a permanência de moradores de rua nos espaços públicos. É o que revela o parecer elaborado em 2010 pela Procuradoria Geral do Município, intitulado "Fundamentos e limites da atuação do poder público na regulamentação dos bens de uso comum do povo, em especial referência no problema da população de rua". 0 ponto principal refere-se às características da função de polícia (Gomes, 2010).

A argumentação fundamenta-se em que o poder de polícia da prefeitura se justifica por sua obrigação de proteção dos bens públicos de uso comum (ruas, calçadas, praças, dentre outros), logo, a Guarda Municipal age para o cumprimento dessa obrigação. Na gestão do espaço urbano, a administração municipal deve aplicar o Código de Postura, permanecendo, assim, dentro da legalidade, ao não permitir que os moradores de rua mantenham, nos logradouros públicos, diversos tipos de objetos. A ação prioritária a ser realizada é a de convencimento para que os objetos sejam retirados e, caso não se obtenha êxito, há previsão do emprego de ação coercitiva, contudo, esta não deve ser com violência e não devem ser recolhidos os documentos das pessoas que moram na rua. Em 2011, o prefeito Márcio Lacerda pronunciou-se em entrevista sobre a preocupação da prefeitura com os moradores de rua e defendeu a administração municipal que fora acusada de promover periodicamente "limpeza urbana" retirando as pessoas de determinadas áreas:

[...] criamos um critério em que o morador de rua não pode se estabelecer na via. Ele pode, no máximo, ficar com o cobertor. A prefeitura tem a obrigação e 0 direito de recolher todos os utensílios que ele estiver carregando. A prefeitura não pode arrastar a pessoa do local. 0 que a gente faz é um trabalho de inclusão ou de localização da família, na cidade de origem. ${ }^{12}$

A remoção de pertences de moradores de rua em Belo Horizonte foi proibida em dezembro de 2012, quando o Tribunal de Justiça do estado de Minas Gerais antecipou tutela (decisão temporária, mas com efeito imediato), impedindo que a prefeitura ou o estado de Minas Gerais realizassem os recolhimentos, sob multa diária em caso de descumprimento. A decisão foi em resposta a uma Ação Civil Pública ajuizada por um coletivo de defesa de direitos humanos.

A decisão do Tribunal de Justiça impedia "especialmente a apreensão de documentos 
de identificação e de pertences necessários à sobrevivência". A prefeitura, levada a suspender temporariamente as ações relacionadas à gestão do espaço urbano e população de rua, preocupou-se, então, em definir quais seriam esses objetos necessários à sobrevivência. Tratava-se, pois, de apresentar uma argumentação que justificasse suas ações. Assim, desencadeou, no âmbito do Comitê de Acompanhamento e Monitoramento da Política Municipal para a População em Situação de Rua, formado por representantes do poder público e da sociedade civil, o processo de elaboração de um documento com orientação e disciplinamento da atuação dos agentes públicos. Não houve consenso, no Comitê, quanto à definição pela prefeitura do que seriam pertences pessoais essenciais à sobrevivência dos moradores de rua. Representantes da sociedade civil entendiam que "não cabe ao poder público, sob a justificativa das normas de posturas e de seu poder de polícia, estabelecer o que é essencial para a sobrevivência das pessoas que se encontram em situação de rua" (Dias et al. 2014).

A prefeitura de Belo Horizonte emitiu, em 2 de dezembro de 2013, a Instrução Normativa Conjunta estabelecendo que a administração municipal pode apreender materiais não essenciais pertencentes às pessoas que vivem nas ruas quando os objetos estiverem obstruindo as vias públicas. Ademais, a instrução regulamentou a atuação dos agentes públicos (policiais, guardas municipais e fiscais) junto à população em situação de rua. Em parágrafo único, a Instrução estabelece que

Quaisquer ações de gestão do espaço público desenvolvidas pelo Poder Público junto à população em situação de rua serão precedidas e sucedidas por:
I - acompanhamento do Serviço Especializado em Abordagem Social; II - esclarecimento sobre as condições de acesso ao acolhimento institucional, respeitadas as especificidades de cada indivíduo, bem como a serviços e programas que integram as políticas públicas de saúde, educação, assistência social, moradia, segurança, cultura, esporte, lazer e trabalho e renda. [...]

Artigo 50: Em nenhuma hipótese, os pertences pessoais essenciais à sobrevivência da população em situação de rua serão objeto de apreensão pelos agentes públi$\cos . \S 1^{\circ}$ - Consideram-se pertences pessoais essenciais à sobrevivência os bens móveis lícitos que o cidadão em situação de rua seja capaz de portar consigo em um só deslocamento e sem auxílio de veículos transportadores, tais como peças de vestuário, alimentos, documentos pessoais, bolsas, mochilas, receituários médicos, medicamentos, cobertores, objetos de higiene pessoal, materiais essenciais ao desenvolvimento do serviço/trabalho, utensílios portáteis, dentre outros. (Belo Horizonte, PBH, 2013)

A Instrução Normativa provocou grande mobilização contrária por parte de entidades que atuam junto aos moradores de rua em Belo Horizonte e do Ministério Público. Após a entrada em vigência das instruções, organizações que se opunham e criticavam as ações da administração municipal entraram com pedido de acesso à informação para conhecer os relatórios das abordagens e os recolhimentos realizados. Neles, constata-se que

a Prefeitura vem recolhendo carrinhos de supermercado, colchões, colchonetes, cobertores, roupas, baldes, produtos de limpeza, vassoura, sombrinhas, dentre outros objetos, além de realizar o desmanche de "cabanas" de papelão". Porém nem 
sempre é possível saber pelos relatórios 0 que foi recolhido nas abordagens. Em muitos casos, os servidores municipais classificaram os pertences da população em situação de rua como "inservíveis" e assim justificava-se que fossem descartados como lixo e não apreendidos. (Dias et al., 2014)

Dentre as críticas à Instrução e ao empenho da prefeitura na sua aplicação, está a afirmação de que as ações visavam mais à limpeza da paisagem urbana (Observatório das Lutas Sociais. Cress 6a região, 2014). A garantia da circulação no espaço urbano do conjunto dos moradores da cidade, que estaria sendo impedida, serviu como pretexto para a normativa.

Em 2016, novamente o Ministério Público de Minas Gerais expediu recomendações à prefeitura de interromper o recolhimento de pertences de moradores de rua e de imediata revogação da instrução normativa. 0 Ministério Público assinalou que a administração municipal não poderia alegar o cumprimento da obrigação legal de gestão do espaço público. A segunda recomendação emitida foi a de desativar um abrigo por motivo de insalubridade.

Em setembro de 2017, a prefeitura de Belo Horizonte apresentou à cidade um plano de revitalização do hipercentro que "abrange estratégias de ampliação das oportunidades de inclusão social e produtiva; a melhoria das condições de segurança para benefício dos comerciantes, dos moradores e dos pedestres; e a geração de condições para o desenvolvimento econômico, por meio do estímulo do uso residencial de prédios vazios e a atração de novos investimentos para o hipercentro". ${ }^{13}$ Na ocasião, a Secretaria Municipal de Serviços Urbanos lembrou que o Código de Posturas do
Município proibia atividades de comércio de camelôs nas ruas. A secretária municipal de Políticas Sociais afirmou que três mil pessoas estavam em situação de rua na cidade, das quais cerca de 1,7 mil transitavam diariamente pelo hipercentro. E agregou:

As principais demandas dos moradores em situação de rua são o acesso à alimentação, documentação, banheiros públicos, tratamentos de saúde, acolhimento institucional e trabalho. Vamos diagnosticar os equipamentos públicos e serviços socioassistenciais da cidade, intensificar a abordagem social, fazer o atendimento nos centros de referências inclusive aos finais de semana, qualificar e ampliar as vagas de acolhimento, além de aumentar as oportunidades de qualificação profissional para essas pessoas.

Por sua vez, o comandante da Guarda Municipal "explicou que o plano de revitalização também inclui a presença de 100 agentes da Guarda em áreas do hipercentro com maior número de ocorrências, principalmente o furto e roubo de celulares". Na imprensa, foi divulgado um pacote de medidas que previa ações voltadas para a gestão do espaço urbano e a desobstrução dos logradouros (Prefeitura de Belo Horizonte, 2017).

No caso da instrução normativa de 2013, em Belo Horizonte, o processo que provocou a sua elaboração e os desdobramentos advindos da sua adoção são reveladores das disputas jurídicas com relação à legalidade das operações feitas pelas prefeituras e do tratamento dados às pessoas em situação de rua. Nessa disputa, participaram alguns dos principais órgãos do sistema de proteção legal, a administração municipal e organizações da sociedade 
civil e entidades do terceiro setor. Nas cidades brasileiras, com frequência, casos como este colocam em oposição prefeituras e Ministério Público, recorrendo-se a argumentos embasados tanto no direito administrativo relacionado à função de administração urbana quanto na Constituição.

Nas cidades brasileiras, operações de remoção de moradores de rua em zonas centrais e áreas onde foram realizados projetos de revitalização não se restringiram ao antes e durante os megaeventos esportivos de 2013 a 2016. Além disso, independentemente de ocorrerem projetos de infraestrutura urbana, são constantemente realizadas por prefeituras ações de remoção de moradores de rua de certas áreas. Tais ações suscitam reações contra e a favor, bem como disputas de narrativas. Os governos municipais argumentam sobre sua obrigação de gestão do espaço urbano e se esforçam em enumerar as ações de promoção social dirigidas à população em situação de rua (equipamentos, restaurante popular, etc.). Seus críticos, por sua vez, denunciam intencionalidade higienista e violação de direitos.

Em Porto Alegre, ocorreu a remoção, pela guarda municipal, dos moradores que viviam embaixo do viaduto Otávio Rocha no centro histórico da cidade, na tarde de sábado de 10 de dezembro de 2016. A operação também contou com representantes da Secretaria Municipal do Meio Ambiente, do Departamento Municipal de Limpeza Urbana, da Brigada Militar e da Fundação de Assistência Social e Cidadania. Foi utilizado o caminhão de lixo para recolher os pertences. A solicitação de remoção dos moradores de rua foi feita à prefeitura pela Associação Representativa e Cultural dos Comerciantes do viaduto Otávio Rocha, justificando a necessidade de preparar o local para a comemoração do aniversário de 84 anos do viaduto que ocorreria no domingo em um evento com atividades de "brechós, sebos, apresentações de atrações musicais, declamações poéticas e teatro de rua, exposição de arte e performances no local". ${ }^{14}$ Questionados pela imprensa e por organizações sociais sobre a remoção, os representantes de cada um dos órgãos da administração municipal envolvidos na ação afirmaram não ter responsabilidade na retirada dos moradores de rua e de seus pertences ou que apenas "fizeram o seu papel". 0 governo municipal afirma que a saída dos moradores do viaduto "foi negociada" e reconhece que possivelmente esses moradores voltariam logo a se instalar no local. 0 importante era, portanto, que eles saíssem, ainda que por um dia, por vontade própria, ou que fossem retirados, para não atrapalhar a realização do evento de reinauguração do viaduto após a reforma.

Na cidade de São Paulo, os decretos relativos à zeladoria urbana foram os principais recursos utilizados pelos prefeitos Fernando Haddad e João Dória para estabelecer o alcance das ações de disciplinamento do uso do espaço público pelos moradores de rua. 0 prefeito João Dória publicou um decreto, em dezembro de 2016, que permitia a retirada de cobertores e pertences de pessoas em situação de rua por guardas municipais. Esse decreto deixou sem efeito um decreto anterior, publicado na gestão de Fernando Haddad, que proibia o recolhimento pela guarda municipal dos itens portáteis de sobrevivência, tais como cobertores, colchonetes, mantas, travesseiros e lençóis. 0 decreto de Haddad fora elaborado após questionamentos feitos à prefeitura pela Defensoria, Ministério Público e entidades 
da sociedade civil, atores que discutiram um marco legal para restringir o poder de polícia da Guarda Civil Municipal contra a população de rua. Apesar dos seus limites e dificuldades de implementação, a normativa foi vista como um avanço na efetivação dos direitos humanos desses segmentos vulneráveis, entre outros motivos porque estabelecia que as ações de zeladoria deveriam preferencialmente serem realizadas das $7 \mathrm{~h}$ às $18 \mathrm{~h}$, de segunda a sexta, para evitar horários em que as pessoas estivessem dormindo à noite. Este e vários outros itens do decreto de Haddad foram alterados pelo prefeito Dória e dariam margem à atuação arbitrária das forças de segurança contra as pessoas que moram na rua. ${ }^{15} 0$ decreto de Dória levou o Ministério Público de São Paulo a instaurar procedimento administrativo que poderia resultar na instauração de um inquérito civil contra a prefeitura. ${ }^{16}$

Em abril de 2016, a Defensoria Pública, em resposta ao recurso apresentado com o apoio do Núcleo Especializado de Cidadania e Direitos Humanos, que desenvolve política especializada de atendimento à população de rua da capital, determinou que a prefeitura de São Paulo devolvesse a um morador de rua seus bens (documentos, roupas, medicamentos e carrinho utilizado para recolher material reciclável) que haviam sido apreendidos no ano anterior pela Guarda Civil Metropolitana. A Defensoria Pública considerou que houve irregularidade na operação, pois o morador de rua não recebeu nenhuma notificação e não fora informado para onde os pertences seriam levados ou como ele poderia recuperá-los. ${ }^{17}$

Os relatos aqui apresentados, das situações e ações nas cidades de Belo Horizonte, Porto Alegre e São Paulo. são parte de um levantamento mais amplo, realizado na mídia e em portais de órgãos públicos, que reuniu informações sobre ações do poder executivo, que são praticamente cotidianas nas ruas das cidades brasileiras, e sobre iniciativas do Ministério Público e das defensorias públicas. Pode-se perceber, a partir delas, que, a propósito dos moradores de rua, há uma queda de braço constante entre administrações municipais (um novo prefeito pode alterar o que o anterior adotou, para fazer exatamente o oposto) e entre estas e órgãos de defesa da ordem jurídica e de fiscalização do poder público. Governos municipais recebem pressões de órgãos de fiscalização, comerciantes e empresários, residentes e imprensa para que ajam para solucionar uma situação vista como crônica na cidade, para que façam com que, em algumas ocasiões (inaugurações, eventos esportivos, etc.), esses moradores não sejam vistos nos espaços urbanos. Sabe-se, no entanto, que na ausência de transformações sociais, econômicas e políticas mais significativas na cidade e no País, os espaços públicos voltarão a ser ocupados pelos mesmos que saíram ou por outros moradores de rua.

Moradores de rua com frequência também são vistos como problema de segurança pública e facilmente associados (pela opinião pública, pelos demais residentes da cidade ou pelas autoridades públicas) à criminalidade urbana e ao crack. Contudo, eles enfrentam cotidianamente insegurança e riscos de violência nas cidades brasileiras. As ameaças durante a noite fazem com que muitos prefiram dormir de dia: "...você nem pode dormir de noite. Porque tem gente que faz 'trairagem'. Tacam fogo, dão paulada, pedrada. A gente tem que ficar mais acordado de noite e dormir de 
dia" (morador de rua em Brasília). ${ }^{18}$ De dia ou à noite, as ameaças podem vir da autoridade pública: "O Rapa leva tudo, se bobear leva você junto" (Carmem, moradora de rua em São Paulo apud Frangella, 2010, p. 204). "Nós não sabíamos que era um índio, pensamos que era um mendigo qualquer" (declaração de defesa pública de um dos jovens que incendiaram o índio Pataxó que dormia na rua em Brasília em 1997. Fonseca, 2005, p. 226 apud Melo, 2011). Em suma, a rua é lugar de vida e de morte, como conclui ao analisar a chacina da Praça da Sé em 2004 (De Lucca, 2016, p. 37).

Vistos como fontes de ameaças, os moradores de rua são eles próprios constantemente ameaçados. 0 serviço Disque 100, criado em 2004 para receber denúncias de violência e violação de direitos, e que destaca os tipos de violência segundo determinados grupos da população, registrou 4.861 denúncias de violência cujas vítimas foram moradores de rua no período entre 2011-2017. ${ }^{19}$

\section{Considerações finais}

A presença de pessoas vivendo nas ruas das cidades impôs-se progressivamente como problema público em grande quantidade de cidades no mundo. Uma questão inicialmente social e territorial transforma-se também em questão humanitária. Do indivíduo perigoso do século XIX que era necessário reprimir, chegou-se à pessoa em perigo do fim do século $X X$, a quem é preciso socorrer. Aquele que há algumas décadas era visto como ameaça para a sociedade e a ordem pública passa a ser visto como uma pessoa em perigo. Não se trata mais de defender a sociedade, mas de salvar o indivíduo. Ao fazerem tais afirmativas, Brodiez-Dolino e Ravon (2015) não se referiam ao Brasil. No entanto, em grandes linhas, poderíamos dizer que se aplicam também às cidades brasileiras se considerarmos que 0 problema público morar na rua deixou de ser apenas uma questão de mendicância, de política e de caridade para ocupar lugar relevante na agenda das políticas sociais, dos direitos humanos e urbanos. Nesse sentido, é possível afirmar, em consonância com a sociologia de problemas públicos, que o fenômeno evoluiu. No entanto, sem ter mudado substancialmente nas suas características essenciais, ele passou a ser percebido, nomeado e tratado de outras maneiras, e, nessa trajetória, tornou-se foco de atenção de uma gama mais ampla e diversificada de atores sociais e instituições.

A adoção da perspectiva de direitos humanos e proteção à vida trouxe para o tema aliados de peso: os operadores do direito, órgãos do sistema de justiça, ministérios públicos e defensorias. Essa nova situação faz lembrar a mudança de patamar e a criação de nova coalizão de defesa ocorrida com relação ao tema das crianças de rua no final dos anos 1980, como analisado por Marôpo (2005). Essa autora atribuiu em parte o novo patamar e a maior visibilidade do problema "criança de rua" ao maior capital social e político e status na hierarquia do poder público dos operadores do direito.

A agenda da ação governamental em relação ao morar na rua tornou-se mais complexa, incorporou outras dimensões, como problema público, e nela está envolvida uma variedade de atores. No período analisado no artigo, foram identificadas diversas frentes de ação do poder público. De um lado, os esforços para estabelecer a política nacional de assistência 
social e a política para a população de rua. De outro lado, no plano municipal, no qual os programas governamentais ganham concretude, há constantes tensões entre as políticas urbana e social, entre a grande publicidade dada às ações de expulsão dos moradores de áreas centrais e a pouca visibilidade das ações rotineiras de atendimento e acolhimento desenvolvidas pelas equipes sociais e de saúde. Em uma visão panorâmica da agenda governamental, percebe-se que varia, segundo a administração de turno em cada prefeitura, a combinação entre repressão, regulação, garantia de direitos e proteção sociais e da vida.

A grande ausente é a política de habitação. Nos últimos anos, os moradores de rua, juntamente com pessoas e famílias que moravam precariamente, mas que ainda não estavam nas ruas, passaram a ocupar imóveis vazios e abandonados nas áreas centrais de algumas das cidades que foram citadas neste texto. As ocupações têm sido a solução para indivíduos e famílias e deram novos formatos ao problema (ou a parte dele) e à disputa pelo espaço urbano e pelo direito à cidade. Diante dessa novidade - as ocupações coletivas organizadas -, os governos municipais encontram-se despreparados para atuar politicamente ou não querem preparar-se nem se responsabilizar. ${ }^{20}$
0 problema do morar na rua interfere na gestão da cidade-negócio, que investe e lucra com o valor do solo urbano, principalmente nas áreas centrais onde vivem e circulam pessoas que moram na rua. Essa cidade choca/ disputa com a insistência e a resistência em habitar a cidade (ruas, bordas, interstícios). Isso ficou evidente com os elementos trazidos na análise sobre a preparação e a realização do megaevento esportivo Copa de 2014. As exigências quanto à configuração das cidades que receberiam os jogos e a tensão crescente com relação à presença dos moradores de rua levaram as prefeituras a agir para retirar essas pessoas e recolher seus pertences de áreas centrais, turísticas e próximas aos estádios. Os governos locais justificavam que, às vésperas e durante o mundial, agiram para "proteger as pessoas que moram nas ruas" e que ocorreram convencimento e acolhimento e não houve recolhimento compulsório. No entanto, os críticos viram ali "violação de direitos", "ações higienistas", "maquiagem dos espaços urbanos", limpando-os de pessoas indesejáveis e pobres, eliminação daquilo que diversos setores achavam que atrapalhava as ruas, prejudicando a imagem da cidade, a segurança dos visitantes e as atividades econômicas.

\section{[I] https://orcid.org/0000-0001-6200-9770}

Pontifícia Universidade Católica de Minas Gerais, Instituto de Ciências Sociais, Programa de Pós-Graduação em Ciências Sociais. Belo Horizonte, MG/Brasil.

cfilgueiras@pucminas.br 


\section{Notas}

(1) Optamos por utilizar a expressão "morar na rua" para nos referir ao fenômeno denominado homelessness na literatura em inglês e sans-abrisme na literatura em francês. Ambos os termos abarcam situações diversas em cada país e, em uma visão abrangente, incluem as condições de estar sem casa, sem teto, sem abrigo, sem domicílio fixo e população em situação de rua (Girola, Jouve e Pichon, 2016).

(2) Este artigo apresenta parte dos resultados do projeto CSA/APQ-03449-16 apoiado pela Fapemig.

(3) O Suas, criado em 2005 e formalizado através de legislação em 2011, é composto por dois níveis de proteção social: a básica (prevenção e promoção das pessoas em vulnerabilidade) e a proteção social especial (com ações destinadas a pessoas em situação de risco social, que têm seus direitos violados ou ameaçados de serem violados, no qual se inserem as que vivem em situação de rua).

(4) Em referência a esses acontecimentos, o dia 19 de agosto passou a ser considerado Dia Nacional de Luta da População de Rua.

(5) A lei n. 11.983, de 16 de julho de 2009, revoga o art. 60 do decreto-lei n. 3.688, de 3 de outubro de 1941 - Lei de Contravenções Penais.

(6) Disponível em: http://www.brasil.gov.br/cidadania-e-justica/2014/06/comite-nacional-se-reunepara-avaliar-atuacao-durante-copa. Acesso em: 14 mar 2018.

(7) Instituído por meio da Secretaria Nacional de Direitos Humanos da Presidência da República, em parceria com o Movimento Nacional da População de Rua, Movimento Nacional dos Catadores de Materiais Recicláveis, Conferência Nacional dos Bispos do Brasil, Pastoral Nacional do Povo da Rua e Ministério Público de Minas Gerais.

(8) Disponível em: http://tribunadoceara.uol.com.br/noticias/politica/higienizacao-projeto-abrigacriancas-e-adultos-em-situacao-de-rua-durante-a-copa-do-mundo/. Acesso em: 26 jun 2019.

(9) Ibid.

(10) Disponível em: http://www.gazetadopovo.com.br/vida-e-cidadania/acao-combate-higienismona-copa-9lu0gv7f9j14lzzeta3jajdxq. Acesso em: 23 abr 2018.

(11) Disponível em: http://www.itatiaia.com.br/noticia/prefeitura-de-bh-cria-acao-para-monitorarmoradores-de-rua-durante-copa-do-mundo. Acesso em: 28 abr 2018.

(12) Disponível em: https://www.em.com.br/app/noticia/gerais/2011/05/31/interna_gerais,230941/ prefeitura-de-bh-apressa-obras-para-a-copa.shtml. Acesso em: 28 abr 2018.

(13) Disponível em: https://prefeitura.pbh.gov.br/noticias/prefeitura-apresenta-plano-derevitalizacao-do-hipercentro. Acesso em: 28 abr 2018.

(14) Disponível em: http://g1.globo.com/rs/rio-grande-do-sul/noticia/2016/12/moradores-de-ruado-viaduto-otavio-rocha-sao-removidos.html. Acesso em: 28 bar 2018.

(15) Disponível em: https://www.cebi.org.br/2017/01/23/higienismo-de-doria-e-a-populacao-derua/. Acesso em: 26 jun 2019.

(16) Disponível em: https://www.otempo.com.br/capa/brasil/mp-questiona-decreto-que-permiteretirar-cobertor-de-morador-de-rua-1.1429004. Acesso em: 28 abr /2018. 
(17) Disponível em: https://odia.ig.com.br/brasil/2018/04/5529803-justica-manda-guarda-municipaldevolver-pertences-a-morador-de-rua.html (publicado em 9/4/2018). Acesso em: 28 abr 2018.

(18) População de rua do Distrito Federal chega a 4 mil pessoas em 2015. Disponível em: https:// noticias.r7.com/distrito-federal/populacao-de-rua-do-distrito-federal-chega-a-4-mil-pessoasem-2015-01072015. Acesso em: 28 abr 2018.

(19) Ministério dos Direitos Humanos. Disque 100. Dados de denúncias - População em Situação de Rua - Nacional. Período 2011-2017. Disponível em: http://www.mdh.gov.br/informacao-aocidadao/ouvidoria/balanco-disque-100. Acesso em: 30 abr 2018.

(20) A tragédia ocorrida em 1 o de maio de 2018, com o incêndio e o desabamento de um prédio ocupado por centenas de pessoas no centro de São Paulo, provocando várias mortes, é demonstração da seriedade da situação.

\section{Referências}

AIEXE, E. (2011). População em situação de rua e o direito à Cidade. Pensar BH/Política Social, n. 29, pp. 5-8.

ARTICULAÇÃO NACIONAL DOS COMITÊS POPULARES DA COPA (2014). Dossiê Megaeventos e Violações de Direitos Humanos no Brasil. Sumário executivo. Disponível em: https://br.boell.org/sites/ default/files/downloads/MegaeventosViolacoesSumario.pdf. Acesso em: 14 mar 2018.

BARBOSA, J. C. (2018). Implementação das políticas públicas voltadas para a população em situação de rua: desafios e aprendizados. Dissertação de Mestrado. Brasília, Instituto de Pesquisa Econômica Aplicada.

BARBOSA, T. (2011). A Copa, a cidade e a vila: um estudo de caso sobre a Vila Recanto UFMG. Monografia. Belo Horizonte, Universidade Federal de Minas Gerais.

BARROS, P. e MONTE, J. (2017). Impactos sociais da Copa do Mundo de 2014: representações sociais de pessoas em situação de rua na Praia de Iracema, em Fortaleza/CE. Revista Humanidades. Fortaleza, v. 32, n. 1, pp. 99-105.

BELO HORIZONTE (2012a). Lei n.10.443, de 28 de março de 2012. Dispõe sobre a Política Municipal de aproveitamento de áreas sob viadutos. Diário Oficial do Município (DOM). Belo Horizonte, 29 de março.

(2012b). Lei n. 10.407, de 12 de janeiro de 2012. Institui o Estatuto do Pedestre. Diário Oficial do Município (DOM). Belo Horizonte, 12 de janeiro.

(2013). Instrução Normativa Conjunta n. 1, de 2 de dezembro. Disciplina a atuação dos agentes públicos junto à população em situação de rua, no município de Belo Horizonte. Diário Oficial do Município (DOM). Belo Horizonte, 7 de dezembro.

BRASIL (2009). Política nacional para a população em situação de rua. Disponível em: <http://www. planalto.gov.br/cciViL_03/_Ato2007-2010/2009/Decreto/D7053.htm. Acesso em: 8 jun 2018. 
BRASIL. MDS (2011). Secretaria Nacional de Renda e Cidadania e Secretaria Nacional de Assistência Social Ministério do Desenvolvimento Social e Combate à Fome - MDS, Orientações técnicas: Centro de Referência especializado para População em situação de Rua e serviço especializado para Pessoas em situação de Rua. Brasília. Disponível em: http://www.mds.gov.br/webarquivos/ publicacao/assistencia_social/Cadernos/orientacoes_centro_pop.pdf. Acesso em: 8 jun 2018.

BRASIL. CAMARA DOS DEPUTADOS (2012). Lei n. 12.663, de 5 de junho de 2012. Disponível em: https:// www2.camara.leg.br/legin/fed/lei/2012/lei-12663-5-junho-2012-613164-normaatualizada-pl. pdf. Acesso: em 28 fev 2019.

BRODIEZ-DOLINO, A. e RAVON, B. (2016). “Le sans-abrisme au XXe siècle: reconfigurations d'1un problème public". In: PICHON, P.; GIROLA, C. e JOUVE, E. (coordonné par). Au temps du sansabrisme: enquêtes de terrain et problème public. Saint-Étienne, Publications de l'Université de Saint-Étienne, pp. 35-56.

CARNEIRO, K. (2016). Moradores de rua e produção do espaço urbano: análise sobre Bogotá e Belo Horizonte sob uma perspectiva genealógica. Tese de Doutorado. Belo Horizonte, Pontifícia Universidade Católica de Minas Gerais.

CASTRO, D. e NOVAE, P. (2015). “Copa do Mundo 2014 e os impactos no direito à moradia: uma análise das cidades-sede brasileiras”. In: SANTOS JR., O.; GAFFNEY, C. e RIBEIRO, L. C. Q. (orgs.). Brasil: os impactos da Copa do Mundo 2014 e das Olimpíadas. Rio de Janeiro, E-papers, recurso digital.

CEFAÏ, D. (2013). Grande exclusão e urgência social - Cuidar dos moradores de rua em Paris. Contemporânea, n. 3, v. 2, pp. 265-286.

(2014). “Investigar los problemas públicos: con y más allá de Joseph Gusfield". In: La cultura de los problemas públicos. El mito del conductor alcoholizado versus la sociedad inocente. Buenos Aires, Siglo XXI, pp. 11-58.

CNDDH - CENTRO NACIONAL de Defesa dos Direitos Humanos da População em Situação de Rua e Catadores de Materiais Recicláveis, (2014). Relatório violações de direitos da população em situação de rua nos meses que antecedem a realização da Copa do Mundo. Disponível em: https://apublica.org/wp-content/uploads/2014/06/Viola\%C3\%A7\%C3\%B5es-Copa-doMundo-12-06-14-1.pdf. Acesso em: 8 jun 2018.

CHOPPIN, K. ; GARDELLA, E.; JOUVE E. e PICHON, P. (2013). La question SDF comme problème public. In: CHOPPIN, K. e GARDELLA, É. (sous la direction de). Les sciences sociales et le sans-abrisme. Saint-Etienne, Publications de l’Université de Saint-Etienne, pp. 101-123.

COMITÊ POPULAR DA COPA E OLIMPÍADAS DO RIO DE JANEIRO (2014). Dossiê Megaeventos e Violações de Direitos Humanos no Rio de Janeiro. Disponível em: https://br.boell.org/mwg-internal/ de5fs23hu73ds/progress?id=GUdHqVZI5c8s6z7yAUJY-MDv4PBVp0xB1_93qTLz3ec Acesso em: 8 jun 2018.

COMITÊ POPULAR DA COPA DE PORTO ALEGRE. Copa do Mundo FIFA 2014 e as Violações de Direitos Humanos em Porto Alegre. Disponível em: https://br.boell.org/sites/default/files/dossie_copa_ poa_bollbrasil.pdf Acesso em: 8 jun 2018.

CONSELHO NACIONAL DO MINISTÉRIO PÚBLICO (2014). Comissão de Defesa dos Direitos Fundamentais - Fórum da Copa. Ministério Público Brasileiro em defesa das pessoas em situação de rua durante a Copa do Mundo. Diretrizes de atuação. Disponível em: http://www.cnmp.mp.br/portal/images/ diretrizes_vers\%C3\%A3o_final_para_ratifica\%C3\%A7\%C3\%A3o.pdf. Acesso em: 26 jun 2019. 
CONSELHO NACIONAL DO MINISTÉRIO PÚBLICO (2015). Guia de Atuação Ministerial: defesa dos direitos das pessoas em situação de rua. Brasília. CNMP. Disponível em: http://www.cnmp.mp.br/portal/ images/Publicacoes/documentos/Guia_Ministerial_CNMP_WEB_2015.pdf. Acesso em: 28 abr 2018.

CPAT. PARCES. (2017). Destapando la olla: informe sombra sobre la intervención en el Bronx. Bogotá. Disponivel em: http://cpatong.com/mwg-internal/de5fs23hu73ds/progress?id=vDKi9qFJqBmA m5IGtx9qVzr3SRgGFIfKIVrIdGINnmE. Acesso em: 14 mar 2018.

DE LUCCA, D. (2016). "Morte e vida nas ruas de São Paulo: a biopolítica vista do centro". In: RUI, T.; MARTINEZ, M. e FELTRAN, G. (orgs.). Novas faces da vida nas ruas. São Carlos, EdUFSCAR.

DEWEY, J. (1927). The public and its problems. Nova York, Henry Hold and Co.

DIAS, A. et al. (2014). "O que é seu não Ihe pertence: as ações de gestão do espaço público em Belo Horizonte envolvendo a população em situação de rua". In: PELLEGRINI, A. et al. (orgs.). Direitos fundamentais das pessoas em situação de rua. Belo Horizonte, D'Plácido, pp. 605-620.

FELTRAN, G. e ARRETCHE, M. (2016). "Apresentação". In: RUI, T.; MARTINEZ, M.; FELTRAN, G. (orgs.). Novas faces da vida nas ruas. São Carlos, EdUFSCAR, pp. 7-8.

FIRKOWSKI, O. e BALISKI, P. (2015). “Elementos para a compreensão das transformações de Curitiba em face da Copa 2014. In: SANTOS JR., O.; GAFFNEY, C. e RIBEIRO, L. C. (orgs.). Brasil: os impactos da Copa do Mundo 2014 e das Olimpíadas. Rio de Janeiro, E-papers, recurso digital, pp. 279-299.

FRANGELLA, S. (2009). Corpos urbanos errantes: uma etnografia da corporalidade de moradores de rua em São Paulo. São Paulo, Anablumme e Fapesp.

(2016). "Prefácio". In: RUI, T.; MARTINEZ, M. e FELTRAN, G. (orgs.). Novas faces da vida nas ruas. São Carlos, EdUFSCAR, pp. 9-14.

GIORGETTI, C. (2006). Moradores de rua: uma questão social? São Paulo, Educ.

GIROLA, C.; JOUVE, É. e PICHON, P. (2016). “Introduction”. In: GIROLA, C.; JOUVE, É. e PICHON, P. (coordonné par). Au temps du sans-abrisme: enquetes de terrain et problème public. Saint-Étienne: Publications de l'Université de Saint-Étienne, pp. 9-29.

GOMES, F. (2010). Fundamentos e limites da atuação do Poder Público na regulamentação dos bens de uso comum do povo, com especial referência ao problema da população em situação de rua Panorama e prognósticos. Revista da Procuradoria-geral municipal de Belo Horizonte. RPGMBH, Belo Horizonte, n. 6, pp. 207-225.

GUSFIELD, J. (2014). La cultura de los problemas públicos. El mito del conductor alcoholizado versus la sociedad inocente. Buenos Aires, Siglo XXI.

HARVEY, D. (1996). Do gerenciamento ao empresariamento: a transformação da administração urbana no capitalismo tardio. Espaço e Debates. São Paulo, n. 39, pp. 48-64.

(2014). Cidades rebeldes: do direito à cidade à revolução urbana. São Paulo, Martins Fontes.

HORNE, J. e MANZENREITER, W. (2006). "An introduction to the sociology of sports megaevents". In: HORNE, J. e MANZENREITER, W. (eds.). Sports mega-events: social scientific analyses of a global phenomenon. (Special Issue: The Sociological Review Monograph Series) v. 54, pp. 1-24.

KASPER, C. (2006). Habitar a rua. Tese de Doutorado. Campinas, Universidade Estadual de Campinas. 
MARÔPO, L. (2005). Movimentos sociais e a construção do discurso mediático sobre a infância no Brasil. Media \& Jornalismo, v. 6, pp. 43-59. Disponível em: http://fabricadesites.fcsh.unl.pt/polocicdigital/ wp-content/uploads/sites/8/2017/02/n6-03-Lidia-Maropo.pdf. Acesso em: 8 jun 2018.

MEDEIROS, R. (2015). "Bêbados, noiados e moradores de rua: efeitos do proibicionismo e desafios das políticas públicas”. In: FERNANDEZ, O. F. R. L. ; ANDRADE, M. e NERY FILHO, A. (orgs.). Drogas e políticas públicas: educação, saúde coletiva e direitos humanos. Salvador, UFBA, pp. 51-65.

MELO, T. (2011). A rua e a sociedade: articulações políticas, socialidade e a luta por reconhecimento da população em situação de rua. Dissertação de Mestrado. Curitiba, Universidade Federal do Paraná.

(2016). “'Da rua pra rua': novas configurações políticas a partir do Movimento Nacional da População de Rua”. In: RUI, T.; MARTINEZ, M. e FELTRAN, G. (orgs). Novas faces da vida nas ruas. São Carlos, EdUFSCAR, pp. 45-65.

MENEZES, T. et al. (2015). Direitos de cidadania: um estudo de casos sobre as implicações da Copa do mundo na população em situação de rua do Município de Salvador. Disponível em: https:// jus.com.br/imprimir/44163/direitos-de-cidadania-um-estudo-de-casos-sobre-as-implicacoesda-copa-do-mundo-na-populacao-em-situacao-de-rua-do-municipio-de-salvador Acesso em: 28 abr 2018.

MINISTÉRIO PÚBLICO DE MINAS GERAIS (2016a). Inquérito Civil n. MPMG-0024.12.0099.33-8. Recomendação 01/2016. Disponível em: https://www.mpmg.mp.br/lumis/portal/file/ fileDownload.jsp?fileld=8A91CFA955C985A40155CC1CCA456698. Acesso em: 26 jun 2019.

(2016b). Inquérito Civil n. MPMG-0024.12007792-0. Recomendação 02/2016. Disponível em: https://www.mpmg.mp.br/lumis/portal/file/fileDownload.jsp?fileld=8A91CFA955C985A40155C C1CC9666667. Acesso em: 26 jun 2019.

NEVEU, E. (2015). Sociologie politique des problèmes publics. Paris, Armand Colin.

OBSERVATÓRIO DAS LUTAS SOCIAIS. CRESS 6a REGIÃO (2014). Em Belo Horizonte, população de rua é vítima da repressão às manifestações e de práticas de "limpeza da cidade" (24/6/2014). Disponível em: http://cress-mg.org.br/hotsites/observatorio-das-lutas-sociais/noticia/25. Acesso em: 28 abr 2018.

PINHEIRO, V.; FREITAS, C.; NOGUEIRA, C. e PEREIRA, A. (2015). “Os impactos da Copa do Mundo da Fifa 2014 em Fortaleza”. In: SANTOS JR., O.; GAFFNEY, C. e RIBEIRO, L. C. (orgs.). Brasil: os impactos da Copa do Mundo 2014 e das Olimpíadas. Rio de Janeiro, E-papers, recurso digital, pp. 301-323.

PREFEITURA DE BELO HORIZONTE (2017). Prefeitura apresenta plano para moradores em situação de rua. Disponível em: https://prefeitura.pbh.gov.br/noticias/prefeitura-apresenta-plano-paramoradores-em-situacao-de-rua. Acesso em: 28 abr 2018.

PREFEITURA DE SÃO PAULO. SECRETARIA MUNICIPAL DE DIREITOS HUMANOS E CIDADANIA (2016). Pesquisa social participativa Pop Rua. Relatório Final. Disponível em: http://www.prefeitura. sp.gov.br/cidade/secretarias/upload/direitos_humanos/Pesquisa\%20Social\%20Participativa. pdf. Acesso em: 28 abr 2018.

PROCURADORIA DA DEFESA DO CIDADÃO (2013). Copa 2014, Olimpíadas 2016 e megaprojetos remoções em curso no Brasil. Disponível em: http://pfdc.pgr.mpf.mp.br/atuacao-e-conteudosde-apoio/publicacoes/direito-a-moradia-adequada/revistas/copa-2014-olimpiadas-2016-emegaprojetos-remocoes-em-curso-no-brasil/view Acesso em: 28 fev 2019. 
PRONI, M. e SILVA, L. (2012). Impactos econômicos da Copa do Mundo de 2014: projeções superestimadas. Texto para Discussão, n. 211. Campinas, Universidade Estadual de Campinas.

REPOLÊS, M. F. e PRATES, F. (2015). A Fifa, a democracia e a soberania: tensões e paradoxos. Sequência. Florianópolis, n. 70, pp. 211-233.

RIBEIRO, L. C. e SANTOS JR., O. (2015). “Governança empreendedorista e megaeventos esportivos: reflexões em torno da experiência brasileira". In: SANTOS JR., O.; GAFFNEY, C. e RIBEIRO, L. C. (orgs.). Brasil: os impactos da Copa do Mundo 2014 e das Olimpíadas. Rio de Janeiro, E-papers, recurso digital, pp. 41-56.

ROLNIK, R. (2013). A um ano da Copa, ganhos e perdas nas cidades-sede. Disponível em: https:// raquelrolnik.wordpress.com/2013/05/16/a-um-ano-da-copa-ganhos-e-perdas-nas-cidadessede/. Acesso em: 26 jun 2019.

ROZENDO, S. e MONTIPÓ, C. (2012). Fora de foco: uma análise da cobertura midiática sobre as pessoas em situação de rua. Revista Ação Midiática, v. 2, n. 1, pp. 1-16.

SANTOS JR., O. (2014). “Apresentação”. In: OLIVEIRA JR., H.; FREITAS, D. e TONUCCI FILHO, J. B. (orgs.). Belo Horizonte: os impactos da Copa do Mundo de 2014. Belo Horizonte, Del Rey e Observatório das Metrópoles, pp. xi-xv.

TONUCCI FILHO, J. B.; SCOTTI, M. e MOTTA, E. (2014). “Copa do Mundo-2014, Belo Horizonte: impactos socioeconômicos e neoliberalismo urbano". In: OLIVEIRA JR., H. R.; FREITAS, D. e TONUCCI FILHO, J. B. (orgs.). Belo Horizonte: os impactos da Copa do Mundo de 2014. Belo Horizonte, Del Rey e Observatório das Metrópoles, pp. 1-31.

Texto recebido em 31/out/2018

Texto aprovado em 24/mar/2019 
